\title{
TO DEVELOP METHOD TO FIND OUT PERMEABILITY AND VOID RATIO FOR PERVIOUS CONCRETE
}

\author{
Dipesh Teraiya $^{1}$, UtsavDoshi ${ }^{1}$, Piyush Viradiya ${ }^{1}$, Ajay Yagnik ${ }^{1}$, Tejas Joshi ${ }^{2}$ \\ ${ }^{1,2,3}$ UG Student, Institute Of Technology, Nirma University (Ahmedabad) \\ (13bcl113@nirmauni.ac.in, 14bcl175@nirmauni.ac.in,13bcl124@nirmauni.ac.in,14bcl177@nirmauni.ac.in) \\ ${ }^{4}$ Asst. Professor, Institute Of Technology, Nirma University (Ahmedabad) \\ (tejas.joshi@nirmauni.ac.in)
}

\begin{abstract}
Synopsis
Concrete is one of the most widely used material in the construction industry. Also many roads are made of concrete base. Many problems are their related to concrete roads in which one of the most leading problem is waterlogging. As there are many uncertainties in rainfall, designed rainwater collection pipe fails due to excessive rainfall and due to which waterlogging over roads occurs. The development of pervious concrete offers promising signs for a change in the way of producing concrete pavements. Void content and permeability of cube was carried out and also void content and permeability of cylinder was carried out. It was found that as the void content increases, permeability increases while compressive strength decreases.
\end{abstract}

Keywords: Void ratio, Permeability, Falling head method

\section{INTRODUCTION}

Pervious concrete which has an open cell helps significantly to provide high permeability due to its interconnected pores. Pervious concrete is a special type of concrete with a high porosity used for concrete at work applications that allows water from precipitation and other sources to pass directly through, thereby reducing the runoff from a site and allowing groundwater recharge. Pervious concrete is made using coarse aggregates with little to no fine aggregates.

In Pervious concrete, accurately and well-proportioned amounts of water and cementitious materials are used to create a cementitious paste that forms a thick coating around the aggregate particles. A pervious concrete mixture contains little or no sand, which creates a structure having a good amount of void content. By using sufficient cementitious paste for coating and binding the aggregate particles together creates a structure of highly permeable, interconnected voids that allows water to drain off quickly.

\section{LITERATURE REVIEW}

\subsection{Void Content}

Void content for pervious concrete ranges from $15 \%$ to $35 \%$. More porosity leads to a high permeability of pervious concrete.

Figure 2.1 shows a general relationship between void ratio and 7-days \& 28-days compressive strength. Compressive strength of pervious concrete reduces as the void ratio increases. For pervious concrete, the void ratio mostly depends on porosity.

\subsection{Compressive strength}

The Pervious concrete has high void content. Due to this, the compressive strength of pervious concrete is lower than that of the conventional concrete. The average compressive strength of pervious concrete is around $15 \mathrm{MPa}$, while the lowest strength of $2.5 \mathrm{MPa}$ and the highest strength of 34.5 $\mathrm{MPa}$ are achieved.

Gyanen.Takhelmayum\&Suresha S.N [1] achieves a compressive strength between 4.3-9.7 $\mathrm{MPa}$ at 7-days and between 7.9-13.2 $\mathrm{MPa}$ at 28-days. The cement content is varying from $250-375 \mathrm{~kg} / \mathrm{m} 3$ It is shown in Figure 2.2 and Figure 2.3.

As per Tennis et.al [2] pervious concrete mixtures attains a compressive strengths in the range of $3.5 \mathrm{MPa}$ to $28 \mathrm{MPa}$. Typical values are about $17 \mathrm{MPa}$. The actual on-place compressive strength is a_ected by the properties and typical range of ingredient materials along with placement techniques and site conditions. The aveage compressive strength of pervious concrete is around $20 \mathrm{MPa}$ while the lowest is of $2.5 \mathrm{MPa}$.

\subsection{Permeability}

Permeability directly depends on the void content of pervious concrete. As the void content increases the permeability increases.

C. Lian and Y. Zhuge[3] found that the trend of permeability is inverse to that of compressive strength for pervious concrete. The minimum point takes place at $\mathrm{w} / \mathrm{c}$ ratio of 0.34 , where the permeability is down to $1.22 \mathrm{~mm} / \mathrm{s}$. Taking the value of 0.34 as a threshold, once the amount of water overran this threshold, the permeability of pervious concrete went up straight, reaching $8.42 \mathrm{~mm} / \mathrm{s}$. It is shown in figure 2.4 . 


\section{Falling Head Test Method}

The falling head method recommended by ACI and developed by Neithalath et al.[4] is used to determine the water permeability of pervious concrete. The schematic diagram of the falling head method for permeability testing is given in figure 2.5 .

The falling head method by Neithalath et al. [4] measures the time taken by water level to fall from initial water head (H1) to the final water head (H2), and waterpermeability is then calculated using Darcy's First Law.

\section{EXPERIMENTAL PROGRAMME}

\subsection{Materials Used}

The materials used were cement of 53 grade OPC, coarse aggregate passing through $20 \mathrm{~mm}$ IS sieve and retained in $10 \mathrm{~mm}$ IS sieve and tap water.

\subsection{Mix Proportion}

The mix proportioning for pervious concrete is different than the usual mix design of normal concrete. For pervious concrete mix design code provision is not available. So the mix design is adopted based on the literature review.As per Table 3.1.

\subsection{Mechanical Properties}

\subsubsection{Compressive Strength}

The compressive strength of pervious concrete is evaluated on a $2000 \mathrm{kN}$ capacity compressive testing machine. For the compressive strength test, cubes of size $150 \mathrm{~mm}$ x $150 \mathrm{~mm}$ x $150 \mathrm{~mm}$ were tested.

Compressive strength $(\mathrm{MPa})=\frac{\mathrm{P} \times 100}{\mathrm{~A}}$

(3.1) where,

$\mathrm{P}=$ Failure load of cube $(\mathrm{kN})$

$\mathrm{A}=$ cross sectional area of cube $(22500 \mathrm{~mm} 2)$

\subsubsection{Void Ratio}

\subsubsection{Void Ratio by Theoretical Approach}

\section{( ASTM C1688 )}

The void content is measured according to ASTM C1688 [5]. The void content is measured as follows.

$$
\begin{aligned}
& \mathrm{D}=\frac{\mathrm{Mc}-\mathrm{Mm}}{\mathrm{Vm}} \\
& \mathrm{T}=\frac{\mathrm{Ms}}{\mathrm{Vs}}
\end{aligned}
$$$$
\text { Void content }(\%)=\frac{\mathrm{T}-\mathrm{D}}{\mathrm{T}} * 100
$$

where,

$\mathrm{Mc}=$ mass of measure filled with concrete

$\mathrm{Mm}=$ mass of measure

$\mathrm{Vm}=$ volume of measure

Ms = total mass of all materials batched

$\mathrm{Vs}=$ sum of absolute volume of each ingredient equal to the quotient of mass of thatingredient divided by the product of its specific gravity times the density of water

Sample Calculation
This sample calculation includes Size B aggregates with 300 $\mathrm{kg} / \mathrm{m} 3$ with $0.3 \mathrm{w} / \mathrm{c}$ ratio and $0 \%$ sand. The value below is average of 5 cubes.

$\mathrm{Mc}-\mathrm{Mm}=32.04 \mathrm{~kg}$

$\mathrm{Vm}=(5 * 0.003375)=0.016875 \mathrm{~m} 3$

$\mathrm{D}=1898.66 \mathrm{Kg} / \mathrm{m} 3$

$\mathrm{Ms}=[5.56875+22.275+1.67025]=29.514 \mathrm{~kg}$

$\mathrm{Vs}=0.01165766 \mathrm{~m} 3$

$\mathrm{T}=2531.7249 \mathrm{~kg} / \mathrm{m} 3$

$\%$ void content $=25 \%$

\subsubsection{Void Ratio By Practical Approach}

1. Weigh the dry concrete sample.

2. Weight the empty container.

3. Fill the container with water at initial level and weigh it.

4. Place the dry sample inside the water container ( approx. $5 \min )$.

5. Empty the water upto initial level and weigh it.

Wsdry = Dry Concrete weight

$\mathrm{Wc}=$ weight of empty container

$\mathrm{Wc}+\mathrm{w}=\mathrm{Weight}$ of container with water at initial level

$\mathrm{Ww} 1=\mathrm{Wc}+\mathrm{w}-\mathrm{Wc}=$ mass of water

$\mathrm{Wc}+\mathrm{w}+\mathrm{s}=$ weight of container with sample with water at initial level

$\mathrm{Ww} 2=\mathrm{Wc}+\mathrm{w}+\mathrm{s}-\mathrm{Wc}-\mathrm{Wsdry}=$ weight of water in the container

$\mathrm{Ww} 3=\mathrm{Ww} 1-\mathrm{Ww} 2=$ Mass of water displaced

$\mathrm{Vw}=\mathrm{Ww} 2 / \gamma \mathrm{w}$

$\%$ of voids $=\frac{\mathrm{Vs}-\mathrm{Vw}}{\mathrm{Vs}} * 100$

\subsubsection{Permeability}

For the measurement of the permeability instrument suggested by the ACI is setup. The falling head method was used to measure the water permeability. Figure 3.1shows the schematic diagram of the permeability test. $300 \mathrm{~mm}$ and 450 $\mathrm{mm}$ waterheads were adopted for measuring permeability. For measuring permeability cylinderof size $150 \times 150 \mathrm{~mm}$ are casted. Cylinder are casted in the PVC pipe. Water permeability is then calculated using Darcy's First Law. The equation is as follows:

$$
\mathrm{K}=\frac{\mathrm{aH}}{\mathrm{At}} *\left(\log \frac{\mathrm{H} 1}{\mathrm{H} 2}\right)
$$


Where,

$\mathrm{k}=$ Coefficient of water permeability

$\mathrm{a}=$ cross-sectional area of graduated cylinder

$A=$ cross-sectional area of specimen

$\mathrm{H}=$ height of the specimen

$\mathrm{t}=$ time

$\mathrm{H} 1$ = the initial water head

$\mathrm{H} 2$ = the final water head

\section{RESULTS AND DISCUSSION}

It was found that permeability is directly proportional to void content as the void content increases permeability also increases and vice-versa. The average compressive strength was around 9 MPaas shown in table 4.1, Void content was nearly $29.8 \%$ as shown in table 4.2 while permeability was ranging from $18-22 \mathrm{~mm} / \mathrm{sas}$ shown in table 4.3.

Fig 4.1 shows the relation between Permeability v/s void ratio

Fig 4.2 shows the relation between compressive strength v/s void ratio

\section{CONCLUSION}

Following are the conclusions draws out from this work

- The average value of permeability ranged between 15 $\mathrm{mm} / \mathrm{sec}$ and $24 \mathrm{mmm} / \mathrm{sec}$, which is within the expected range found in literature.

- Compressive Strength value which is also within the desirable range of $7 \mathrm{MPa}$ to $12 \mathrm{MPa}$.

- $\quad$ Fig. 4.1 shows the relation between the Void ratio and Permeability. As the Void ration increases the Permeability also increases.

- Fig. 4.2 shows the relation between the Void ration and Compressive strength. As the Void content increases the Compressive strength decreases.

\section{NOTATIONS}

$\mathrm{a}=$ cross-sectional area of graduated cylinder

$\mathrm{A}=$ cross-sectional area of specimen

$\mathrm{ACI}=$ American Concrete Institute

ASTM $=$ American standard for Testing Material

$\mathrm{H}=$ height of the specimen

$\mathrm{H} 1=$ the initial water head

$\mathrm{H} 2$ = the final water head

$\mathrm{k}=$ Coefficient of water permeability

$\mathrm{kN}=$ kilo newton

$\mathrm{Mc}=$ mass of measure filled with concrete

$\mathrm{Mm}=$ mass of measure

$\mathrm{mm}=$ millimeter
$\mathrm{MPa}=$ mega pascal

$\mathrm{Ms}=$ total mass of all materials batched

OPC = Ordinary Portland Cement

PVC = Polyvinyl Chloride

$\mathrm{t}=$ time

$\mathrm{Vm}=$ volume of measure

$\mathrm{Vs}=$ sum of absolute volume of each ingredient equal to the quotient of mass of thatingredient divided by the product of its specific gravity times the density of water

$\mathrm{Vw}=$ Volume of Water

$\mathrm{Wc}=$ weight of empty container

$\mathrm{Wc}+\mathrm{w}=\mathrm{Weight}$ of container with water at initial level

$\mathrm{Wc}+\mathrm{w}+\mathrm{s}=$ weight of container with sample with water at initial level

Wsdry $=$ Dry Concrete weight

$\mathrm{Ww} 1=$ mass of water

Ww2 =weight of water in the container

Ww3 = Mass of water displaced

$\gamma \mathrm{w}=$ Unit weight of water

\section{REFERENCES}

[1] Gyanen.Takhelmayum and Suresha S.N, IEvaluation of Compressive Strengthof Pervious Concrete using River sand", International Journal of Engineeringand Social Science, Volume 2, Issue 11, November, 2012.

[2] Paul D. Tennis, Michael L. Leming, and David J. Akers, IPervious ConcretePavements", Portland Cement Association, ISBN 0-89312-242-4, PCA SerialNo. 2828 , 2004.

[3] C.Lian, Y. Zhuge and S. Beecham, IThe relationship between porosity andstrength for porous concrete", Journal of Construction and Building MaterialsVol.25, 42944298, 2011

[4] Narayanan Neithalath, ICompressive response of pervious concretes proportioned for desired porosities", Construction and Building Materials, May 2011.

[5] ASTM C1688, Standard Test Method for Density and Void Content of FreshlyMixed Pervious Concrete.

[6] George N. McCain and Mandar M. Dewoolkar , "Porous Concrete Pavements: Mechanical and Hydraulic Properties ”, June 2006 


\section{TABLES AND FIGURES}

\subsection{Figures}

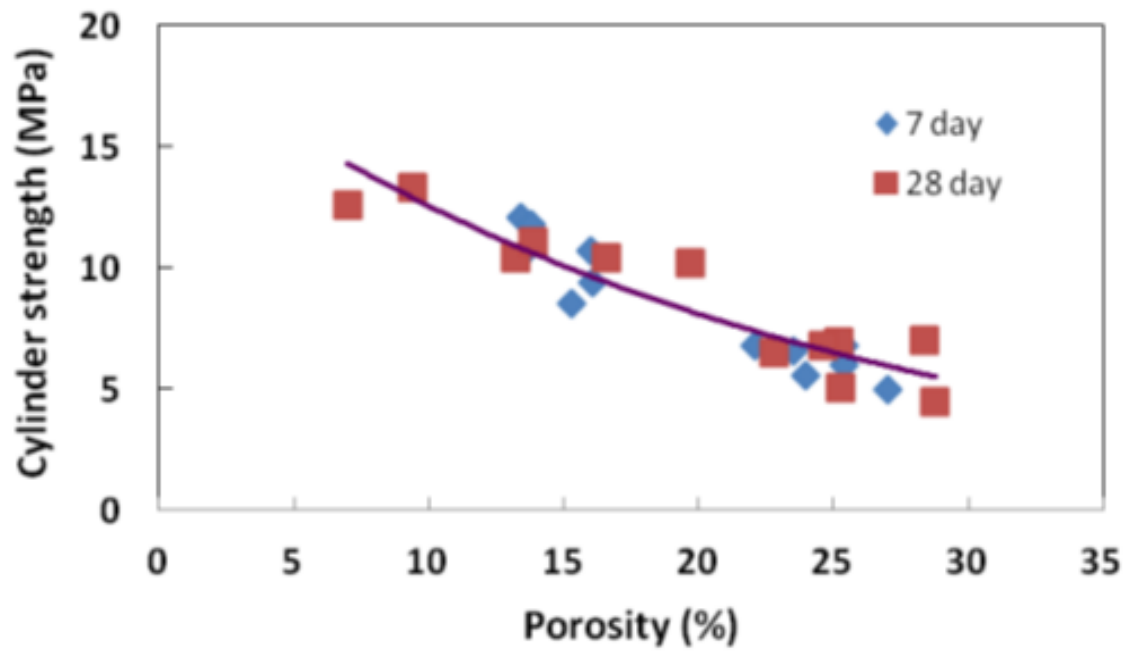

Figure 2.1: Relationship between void ratio and compressive strength

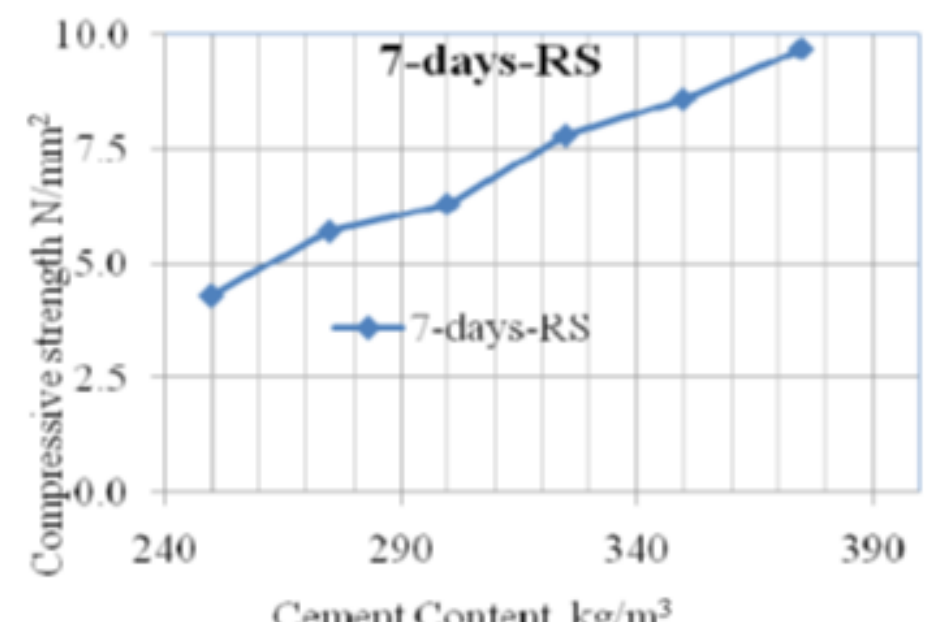

Figure 2.2: Compressive strength for a curing period of 7-day.

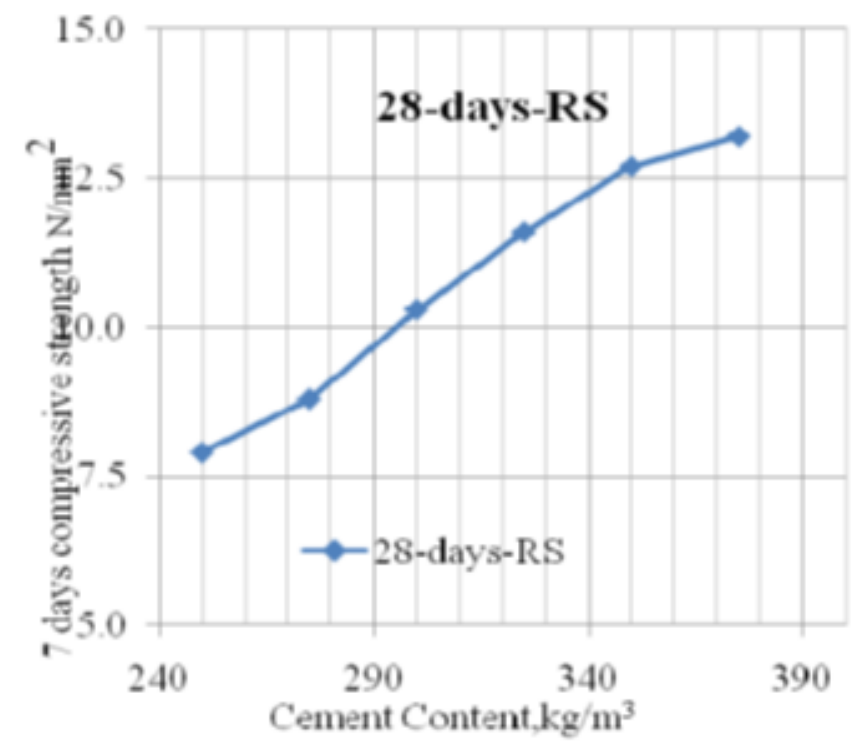

Figure 2.3: Compressive strength for a curing period of 28-day 


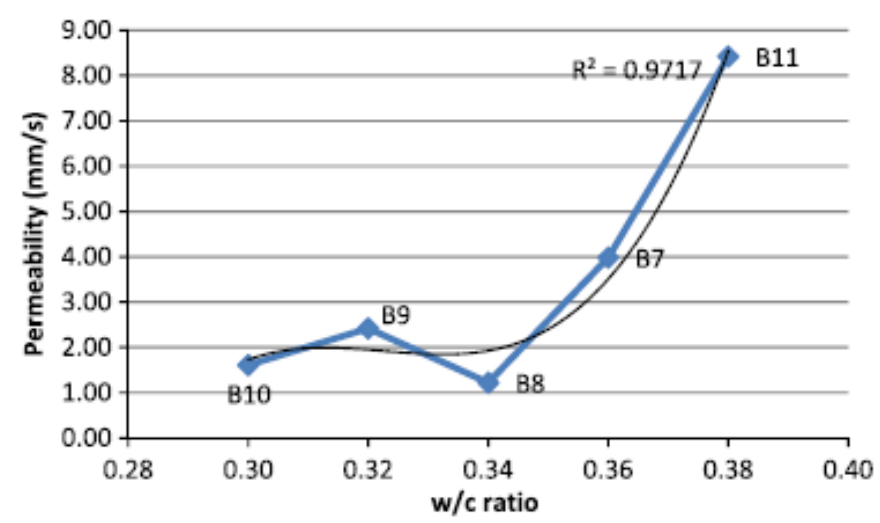

Figure 2.4: Relationship between w/c ratio and permeability

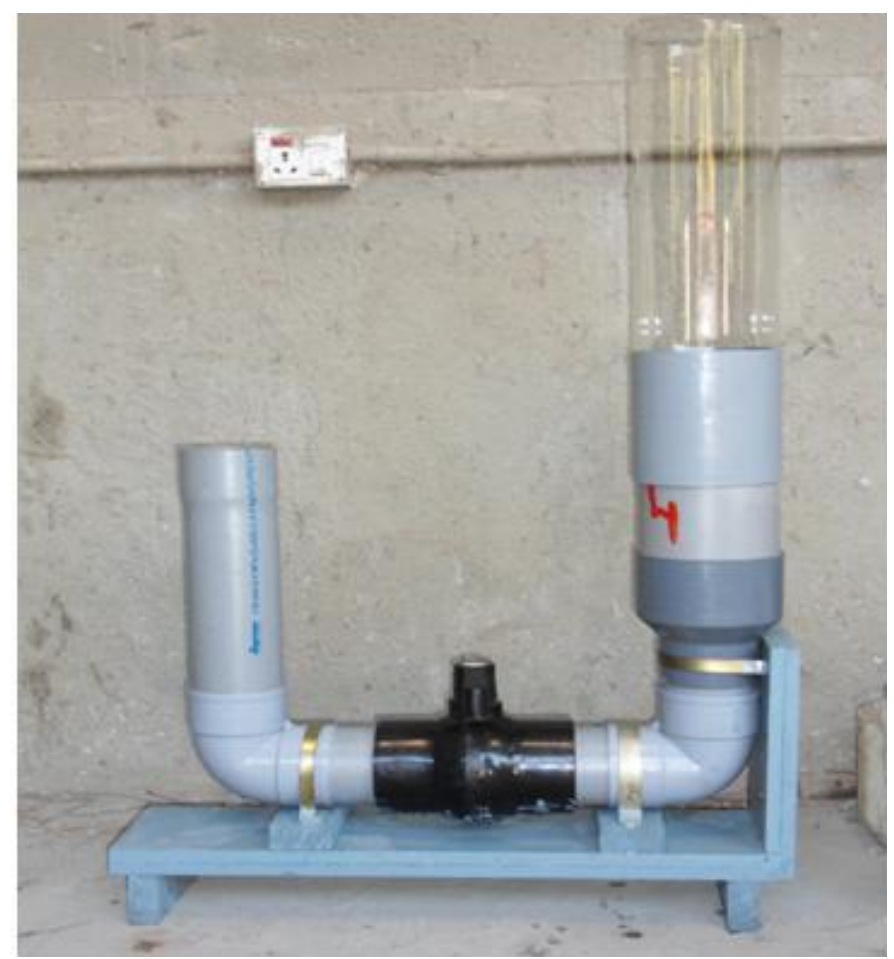

Figure 3.1: Falling head method for permeability testing

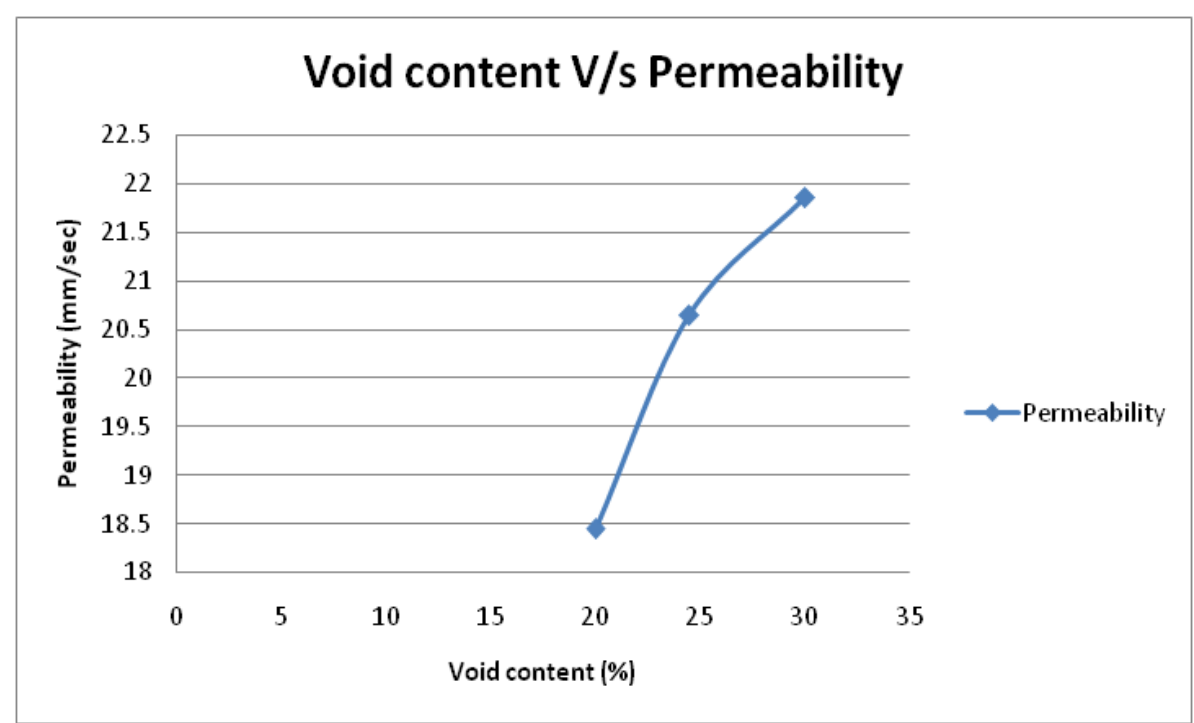

Fig 4.1 Relation between void content and Permeability 


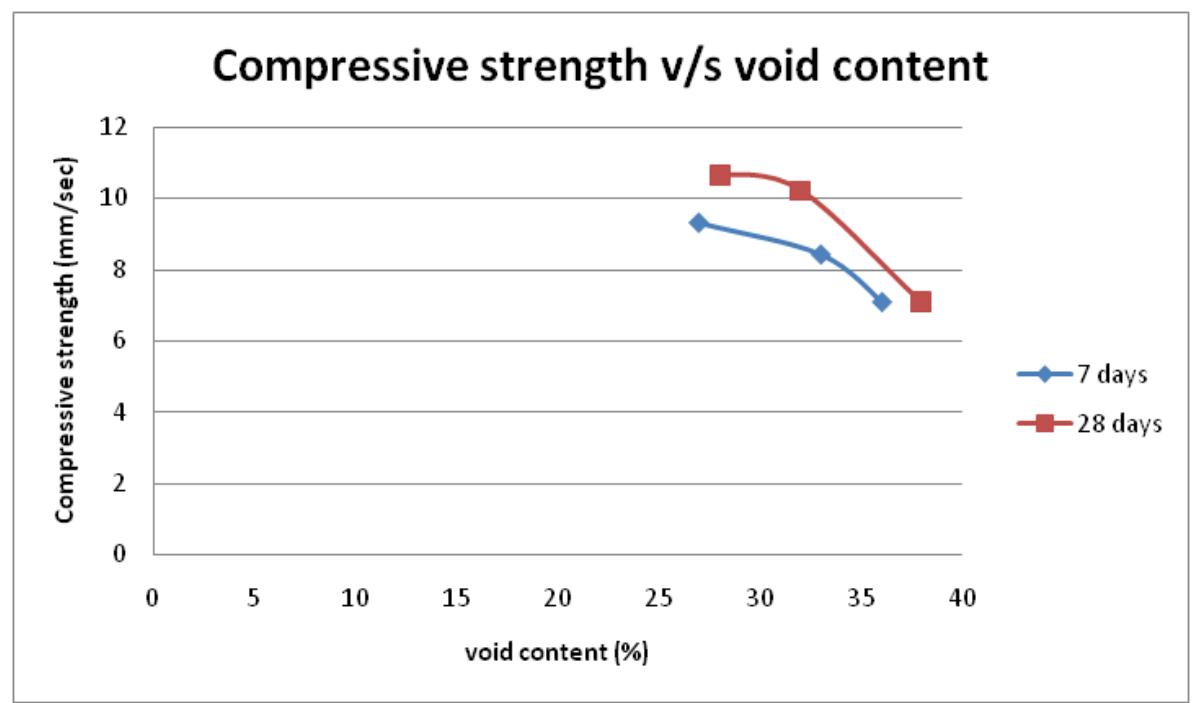

Fig 4.2 Relation between compressive strength v/sVoid content

\subsection{Tables}

able 3.1 Mix Design

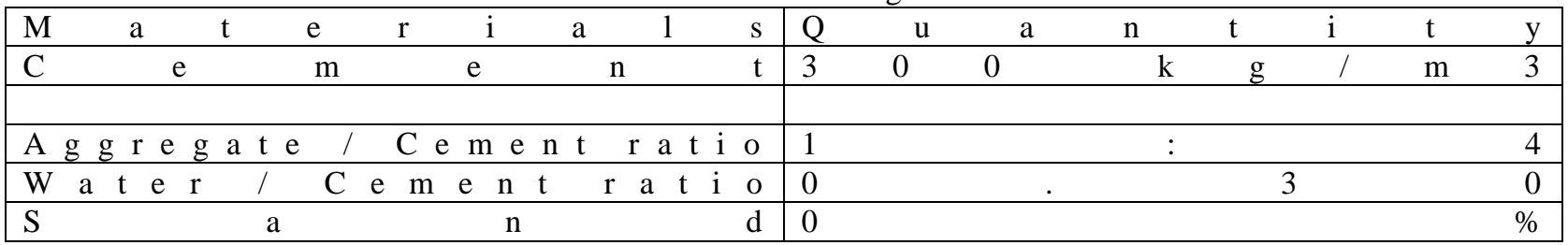

Table 4.1 Compressive strength

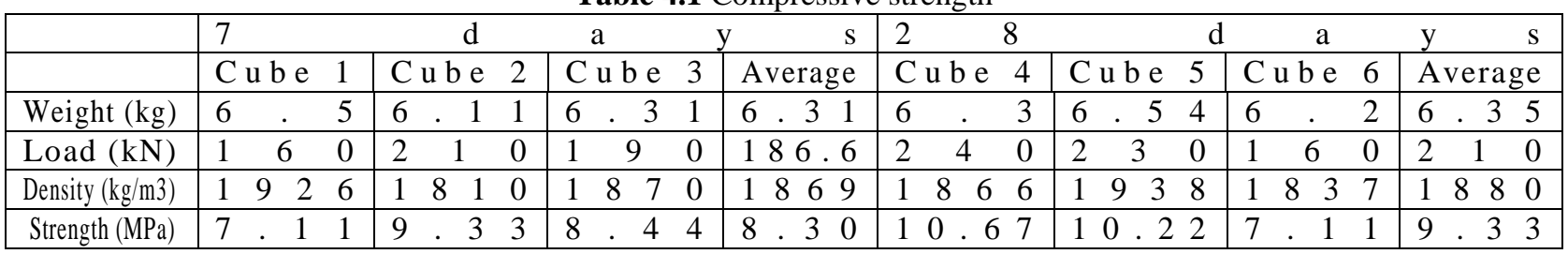

Table 4.2 Void Ratio Calculation

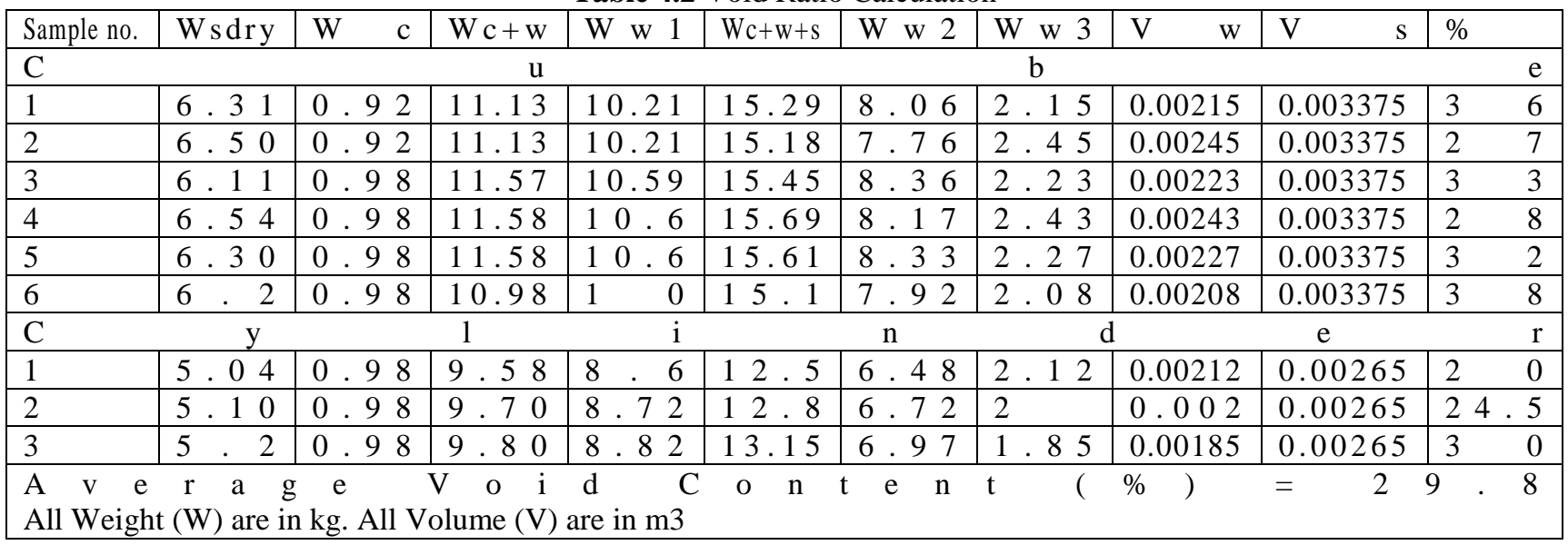

Table 4.3 Permeability by falling head method

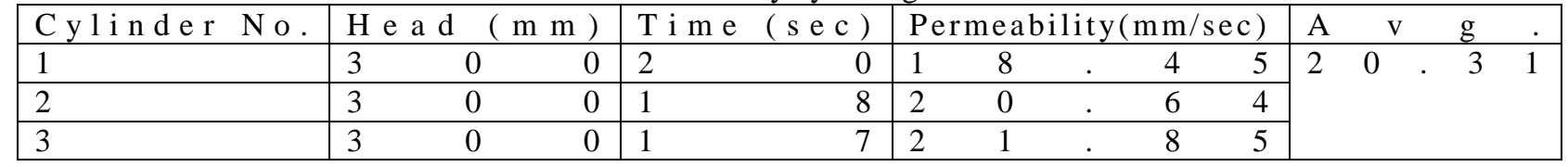

